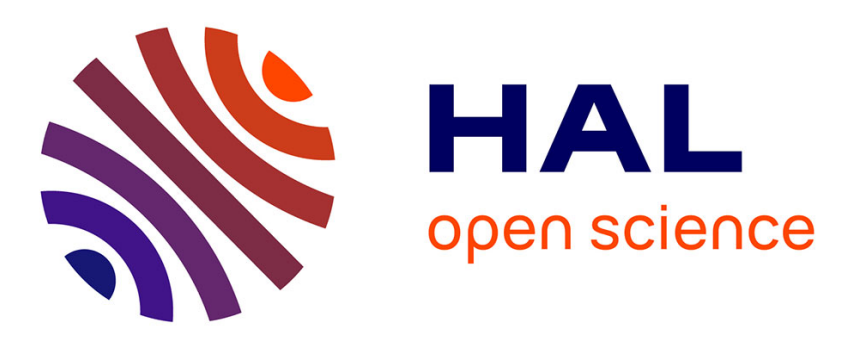

\title{
Phase Separation in Supramolecular Hydrogels Based on Peptide Self-Assembly from Enzyme-Coated Nanoparticles
}

Miryam Criado-Gonzalez, Jennifer Rodon Fores, Alain Carvalho, Christian Blanck, Marc Schmutz, Leyla Kocgozlu, Pierre Schaaf, Loïc Jierry, Fouzia Boulmedais

\section{To cite this version:}

Miryam Criado-Gonzalez, Jennifer Rodon Fores, Alain Carvalho, Christian Blanck, Marc Schmutz, et al.. Phase Separation in Supramolecular Hydrogels Based on Peptide Self-Assembly from EnzymeCoated Nanoparticles. Langmuir, 2019, 35 (33), pp.10838-10845. 10.1021/acs.langmuir.9b01420 . hal-02481275

\section{HAL Id: hal-02481275 \\ https://hal.science/hal-02481275}

Submitted on 17 Feb 2020

HAL is a multi-disciplinary open access archive for the deposit and dissemination of scientific research documents, whether they are published or not. The documents may come from teaching and research institutions in France or abroad, or from public or private research centers.
L'archive ouverte pluridisciplinaire HAL, est destinée au dépôt et à la diffusion de documents scientifiques de niveau recherche, publiés ou non, émanant des établissements d'enseignement et de recherche français ou étrangers, des laboratoires publics ou privés. 


\section{Phase Separation in Supramolecular Hydrogels}

\section{Based on Peptide Self-Assembly from Enzyme-}

\section{coated Nanoparticles}

Miryam Criado-Gonzalez, ${ }^{a, b, c}$ Jennifer Rodon Fores, ${ }^{a}$ Alain Carvalho, ${ }^{a}$ Christian Blanck, ${ }^{a}$ Marc

Schmutz, ${ }^{a}$ Leila Kocgozlu ${ }^{b, c}$ Pierre Schaaf, ${ }^{* a, b, c}$ Loïc Jierry, ${ }^{* a}$ Fouzia Boulmedais ${ }^{a}$

a. Université de Strasbourg, CNRS, Institut Charles Sadron UPR 22, 67034 Strasbourg, France.

b. Institut National de la Santé et de la Recherche Médicale, UMR-S 1121, "Biomatériaux et Bioingénierie", 67087 Strasbourg, France.

c. Université de Strasbourg, Faculté de Chirurgie Dentaire, Fédération de Médecine Translationnelle de Strasbourg and Fédération des Matériaux et Nanoscience d'Alsace, 67000 Strasbourg, France.

KEYWORDS: self-assembly, peptides, nanoparticles, fibers, hydrogels, enzyme 


\section{ABSTRACT}

Spatial localization of biocatalysts, such as enzymes, has recently proven to be an effective process to direct supramolecular self-assemblies in a spatiotemporal way. In this work, silica nanoparticles functionalized covalently by alkaline phosphatase (NPs@AP) induce the localized growth of selfassembled peptide nanofibers from NPs by dephosphorylation of Fmoc-FFpY peptides (Fmoc: Fluorenylmethyloxycarbonyl; F: phenylalanine; Y: tyrosine; $p$ : phosphate group). The fibrillary nanoarchitecture around NPs@AP underpins a homogeneous hydrogel which unexpectedly undergoes a macroscopic shape change over time. This macroscopic change is due to a phase separation leading to a dense phase (in NPs and nanofibers) in the center of the vial and surrounded by a dilute one which still contains NPs and peptides self-assemblies. We thus hypothesize that the phase separation is not a syneresis process. Such a change is only observed when the enzymes are localized on the NPs. The dense phase contracts with time until reaching a constant volume after several days. For a given phosphorylated peptide concentration, the dense phase contracts faster when NPs@AP concentration is increased. For a given NPs@AP concentration, it condenses faster when the peptide concentration increases. We hypothesize that the appearance of a dense phase is not only due to attractive interactions between NPs@AP but also to the strong interaction of self-assembled peptide nanofibers with the enzymes, covalently fixed on the NPs. 


\section{Introduction}

In a highly simplified vision, living organisms can be considered as assemblies of multi-stimuli responsive systems able to adapt to surrounding environmental changes. Stimulated by the ambition to create artificial living matter, ${ }^{1-8}$ the research community has focused its investigations toward the design of materials sensitive to external stimuli. ${ }^{9}$ Mainly through bioinspired strategies, this engagement has given rise to the so-called class of smart materials. Currently one main challenge is to control this responsiveness in space and over time. ${ }^{10-15}$ Along this route, spatial localization of (bio)catalysts has recently proven to be an effective process to direct supramolecular self-assemblies in a spatiotemporal way. ${ }^{16-20}$ Localization of (bio)catalysts in space allows inducing the chemical switch from non-self-assembling entities into self-assembling ones, leading to a spontaneous self-assembly process occurring exclusively and specifically near the (bio)catalyst localization. Ulijn and co-workers have first shown that the immobilization of thermolysin on a glass substrate followed by the contact with a mixture of Fmoc-L and LL dipeptide ( $\mathrm{L}=$ Leucine) allows the self-assembly nucleation of Fmoc- $\mathrm{L}_{\mathrm{n}}$ spatially controlled from the enzymatically-active surface. ${ }^{21}$ This approach has been successfully used to entrap laminin inside a localized hydrogel for therapeutic applications. ${ }^{22}$ Recent works using different enzyme/peptide systems showed that by adsorbing the enzymes on multilayer films, the resulting self-assembled nanoarchitecture can be tuned by playing on various parameters such as the enzyme density, ${ }^{23}$ the presence of a seeding layer ${ }^{24}$ or the glucose concentration for instance. ${ }^{25}$ In 2018 , the group of van Esch showed that the growth of supramolecular fibers can be spatially localized at the nanoscale by using negatively charged polystyrene nanoparticles facilitating the acid-catalyzed formation of hydrogelators. ${ }^{26}$ The properties of the resulting gel (gelation time, mechanical properties and network morphology) have been modified by the presence of nanoparticles. Wang 
et al. described the development of core-shell nanogels using the self-assembly of a suitable peptide on silica NPs previously functionalized by enzymes. ${ }^{27}$ Conte et al. reported also the covalent grafting of enzymes onto magnetic nanoparticles (NPs) allowing the nucleation of selfassembled nanofibers from the surface of NPs using a suitable hydrogelator precursor. ${ }^{28}$ The resulting hydrogel could be macroscopically deformed through the simple external use of a magnet placed near the vial-containing hydrogel. Permanent new shape was obtained after one month of interaction with a magnetic field, resulting in a squeezing of the initial NP-based hydrogel, separating it from water.

a

Fmoc-FFpY

Fmoc-FFY
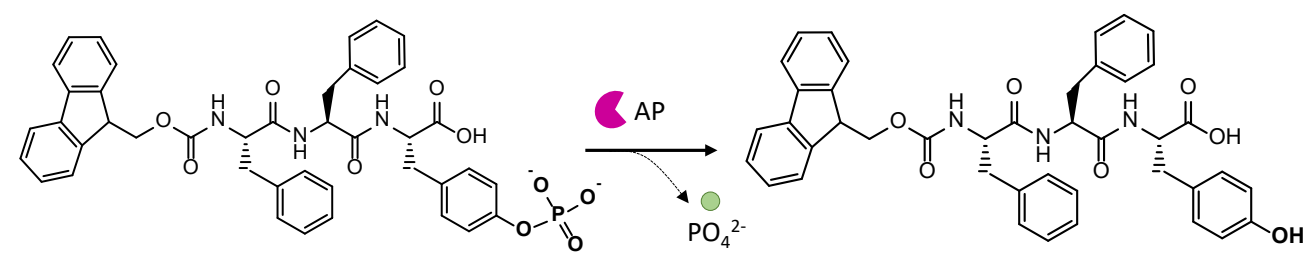

b

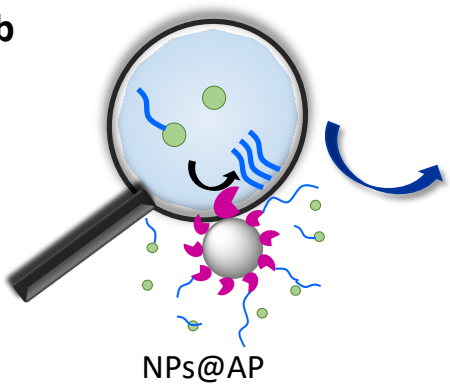

C
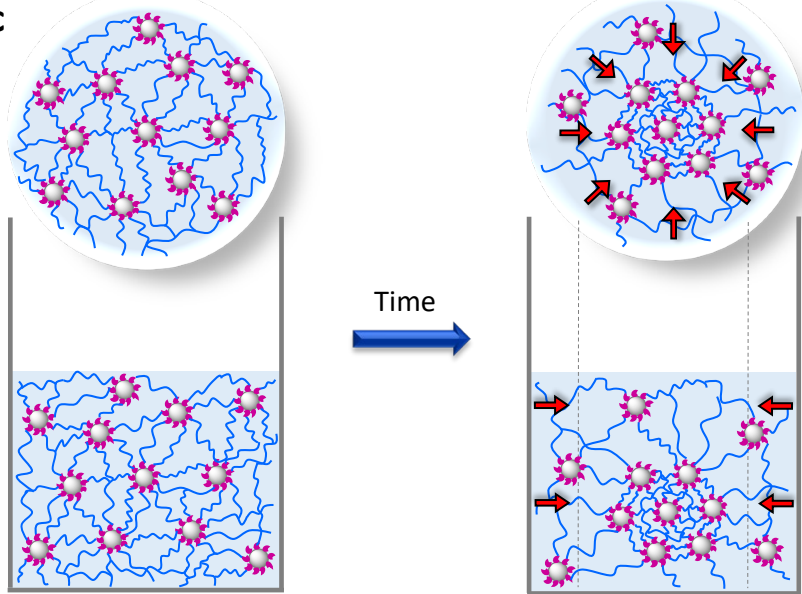

Scheme 1. (a) Fmoc-FFpY dephosphorylation by AP leading to the gelator Fmoc-FFY. Schematic representations of (b) Fmoc-FFY nanofibers (in blue) self-assembled from NP@AP by dephosphorylation of Fmoc-FFpY leading to (c) a hybrid supramolecular hydrogel undergoing a phase separation over time. 
Here, we report the design of a hybrid supramolecular hydrogel prepared from Fmoc-FF $p Y$ tripeptide (F: phenylalanine, Y: tyrosine, $p$ : phosphate group) and silica NPs functionalized covalently by alkaline phosphatase (AP). AP transforms Fmoc-FFpY in Fmoc-FFY, an efficient hydrogelator, able to self-assemble spontaneously and exclusively from the surface of NPs leading to the formation of a homogeneous nanofibrous network (Scheme 1). Unexpectedly, the hybrid supramolecular hydrogel undergoes a macroscopic change over time due to a phase separation leading to one phase, in the center of the vial, denser in NPs and in peptide fibers than the other surrounding phase.

\section{Materials and Methods}

Materials. Tetraethyl orthosilicate (TEOS), (3-glycidyloxypropyl) trimethoxysilane (GPMS), phosphatase alkaline from bovine intestinal mucosa (AP) (10 DEA units/mg protein) and $p$ Nitrophenyl Phosphate Liquid Substrate System (PNP) were provided by Sigma Aldrich. Sodium tetraborate anhydrous (borax) and dry toluene were supplied by Acros Organics. Fmoc-FFpY was purchased by PepMic, ammonium hydroxide by Carlo Erba and ethanol in VWR.

Synthesis and functionalization of silica nanoparticles. Silica nanoparticles (NPs) were synthetized following the procedure described elsewhere. ${ }^{29-30}$ Briefly, $80 \mathrm{~mL}$ of ethanol, $4.85 \mathrm{~mL}$ of Milli-Q water and $3.6 \mathrm{~mL}$ of $\mathrm{NH}_{4} \mathrm{OH}$ were mixed in a two necks flask under mechanical stirring (400 rpm) and heated up to $55^{\circ} \mathrm{C}$. When the temperature is reached, $8 \mathrm{~mL}$ of ethanol and $3.1 \mathrm{~mL}$ of TEOS, mixed in a separated vial, were added quickly to the previous solution and kept under stirring for $5 \mathrm{~h}$. In a second step in order to obtain larger nanoparticles from the first synthesis ( $80 \mathrm{~nm}), 10 \mathrm{~mL}$ of the NPs colloidal suspension were mixed with $70 \mathrm{~mL}$ ethanol, $13 \mathrm{~mL}$ Milli-Q water and $7.5 \mathrm{~mL}$ of $\mathrm{NH}_{4} \mathrm{OH}$ in a two necks flask and heated again up to $55^{\circ} \mathrm{C}$ under mechanical 
stirring (400 rpm). When the temperature is reached, a mixture of $10 \mathrm{~mL}$ of ethanol and $1 \mathrm{~mL}$ of TEOS was added dropwise to the solution and kept under stirring for $5 \mathrm{~h}$. Subsequently, the solution was centrifuged (6000 rpm, $20 \mathrm{~min}$ ) and the precipitate of NPs was washed three times with ethanol by centrifugation ( $6000 \mathrm{rpm}, 20 \mathrm{~min})$. For the covalent immobilization of AP, $2.5 \mathrm{~mL}$ of NPs were dried at $100^{\circ} \mathrm{C}$ under argon atmosphere for $2 \mathrm{~h}$ in a $50 \mathrm{~mL}$ flask. Then, $10 \mathrm{~mL}$ of 5\%v/v GPMS in dry toluene were added to dry NPs. The suspension was sonicated for 10 min to avoid aggregates and kept shaking at $720 \mathrm{rpm}$ overnight at room temperature. The obtained epoxyfunctionalized NPs were centrifuged and the precipitate was firstly washed three times with toluene to remove unbounded GPMS and subsequently, three times with ethanol to remove toluene. The final NPs were dispersed in $1 \mathrm{~mL}$ of ethanol and subsequently added dropwise to an aqueous solution of AP $\left(1 \mathrm{mg} \cdot \mathrm{mL}^{-1}\right.$ in borax buffer $\left.(25 \mathrm{mM}, \mathrm{pH}=9.5)\right)$ and kept shaking for $24 \mathrm{~h}$ at $4^{\circ} \mathrm{C}$. Then, NPs were centrifuged and washed five times with borax buffer $(25 \mathrm{mM}, \mathrm{pH}=9.5)$ to remove the unbounded enzyme. NPs@AP showed an activity equivalent to 30 units.mL $\mathrm{mL}^{-1}$ with a solid content of $5 \%$ (w/v). Finally, NPs@AP were redispersed in $1 \mathrm{~mL}$ borax buffer $(25 \mathrm{mM}, \mathrm{pH}$ $=9.5$ ) and stored at $4^{\circ} \mathrm{C}$ until needed.

Dynamic Light Scattering (DLS). DLS experiments were carried out in a Malvern Nanosizer ZS with a measurement angle of $173^{\circ}$ and collecting five spectra per sample at $25^{\circ} \mathrm{C}$. To determine the hydrodynamic diameter of NPs, $7 \mu \mathrm{L}$ of as-prepared NPs (5\% w/v) were diluted in $1.4 \mathrm{~mL}$ of ethanol. Kinetic measurements were carried out by placing first in a plastic cuvette $7 \mu \mathrm{L}$ of NPs@AP $(5 \%$ w/v) diluted in $400 \mu \mathrm{L}$ borax buffer $(25 \mathrm{mM}, \mathrm{pH}=9.5)$ and then, $1 \mathrm{~mL}$ of FmocFFpY $\left(0.1\right.$ and $1 \mathrm{mg} \cdot \mathrm{mL}^{-1}$ in borax buffer $\left.(25 \mathrm{mM}, \mathrm{pH}=9.5)\right)$. Spectra were recorded at different time intervals. 
Transmission Electron Microscopy (TEM). TEM images were taken in a Technai G2 machine in negative coloration. To determine the average size of NPs, $10 \mu \mathrm{L}$ of a diluted solution of NPs in ethanol were placed over a carbon-coated copper grid. To observe the peptide fibers, $5 \mu \mathrm{L}$ of NPs@AP $(0.03 \%$ w $/ v)$ were dropped off on the grid followed by the addition of $5 \mu \mathrm{L}$ of FmocFFp $\mathrm{Y}\left(0.1 \mathrm{mg} \cdot \mathrm{mL}^{-1}\right.$ in borax buffer $(25 \mathrm{mM}, \mathrm{pH}=9.5)$ for $30 \mathrm{~min}$ before observation.

Infrared spectroscopy. The Fourier Transform Infrared (FTIR) experiments were performed on a Vertex 70 spectrometer (Bruker, Germany) using DTGS detector. Spectra were recorded in the Attenuated Total Reflection (ATR) mode by collecting 128 interferograms between 600 and 4000 $\mathrm{cm}^{-1}$ at $2 \mathrm{~cm}^{-1}$ resolution, using Blackman-Harris three-term apodization and the standard Bruker OPUS/IR software (version 7.5). For NPs and NPs@AP, $200 \mu \mathrm{L}$ of each solution were dried before recording the spectra. In the case of Fmoc-FFpY solution $\left(10 \mathrm{mg} \cdot \mathrm{mL}^{-1}\right)$ and Fmoc-FFY hydrogel, obtained from a mixture of $1.25 \%$ w/v NPs@AP (eq. [AP] $=7.5$ units.mL ${ }^{-1}$ ) and 1 mg.mL ${ }^{-1}$ Fmoc$\mathrm{FF} p \mathrm{Y}$, samples were prepared in deuterated water.

UV spectroscopy. The enzymatic activity of NPs@AP was determined by measuring the absorbance at $\lambda=405 \mathrm{~nm}$ as a function of time using a microplate reader UV spectroscopy (FLXXenius ${ }^{\circledR}$, SAFAS, Monaco). PNP is a colourless substrate, by sequential enzymatic hydrolysis of the phosphate substituent of PNP in presence of AP yields a yellow absorbance at $\lambda=405 \mathrm{~nm}$. Incubation of $150 \mu \mathrm{L}$ (at $1 \mathrm{mM}$ in borax buffer) of PNP was performed for different concentrations of AP in solution to determine the calibration curve, i.e. slope of the absorbance $v$ s time as a function of AP concentration. The slope obtained for NPs@AP solution in contact with PNP allows to determine the concentration in AP. Concentration and volume used ensure a large excess of substrate for the enzymatic reaction. 
Fluorescence spectroscopy. All fluorescence spectra were recorded between 305-345 nm using the microreader fluorescence spectroscopy (FLX-Xenius ${ }^{\circledR}$, SAFAS, Monaco) at an excitation wavelength of $290 \mathrm{~nm}$ and a specific 96 well-plate. $50 \mu \mathrm{L}$ of NPs@AP (5\% w/v) were put in contact with $150 \mu \mathrm{L}$ of $1 \mathrm{mg} \cdot \mathrm{mL}^{-1}$ Fmoc-FFpY solution to follow the formation of Fmoc excimer due to Fmoc-FFY self-assembly.

Hydrogel formation. All solutions were prepared in borax buffer $(25 \mathrm{mM}, \mathrm{pH}=9.5) .150 \mu \mathrm{L}$ of Fmoc-FFpY were mixed with $50 \mu \mathrm{L}$ of one of the following compounds: AP, NPs or NPs@AP in vials. After 24, 48 and $72 \mathrm{~h}$, inverted tube tests were carried out to determine the hydrogel formation. Fmoc-G was used as control.

Scanning Electron Microscopy (SEM) and Cryo-SEM. To observe the morphology of the gels, a specific cryo-holder and a cryo preparation chamber were designed and manufactured by the mechanical facility of the Charles Sadron Institute. ${ }^{23}$ A piece of the gel was placed on the cryoholder to be quickly plunged into an ethane slush. As the sample is free standing over the holder, the sample is rapidly frozen during the plunging by direct contact with the liquid ethane. Subsequently, the sample is transferred into the Quorum PT 3010 chamber attached to the microscope. There, the frozen sample is fractured with a razor blade. A slight etching at $-90^{\circ} \mathrm{C}$ may be performed to render the fibers more visible. The sample is eventually transferred in the FEG-cryo SEM (Hitachi SU8010) and observed at $1 \mathrm{kV}$ at $-150^{\circ} \mathrm{C}$.

Analytic High-Performance Liquid chromatography (HPLC). HPLC was carried out with 1100 Series from Agilent technologies. The column is a Supelcosil ABZ + Plus with the following dimensions $15 \mathrm{~cm} \times 4.6 \mathrm{~mm}, 3 \mu \mathrm{m}$. The eluent used for all analyses was acetonitrile/deionized water in a ratio $90 / 10$ in isocratic conditions, at $1 \mathrm{~mL} \cdot \mathrm{min}^{-1}$ with a run time of $25 \mathrm{~min}$. 
Chromatograms were recorded by the software OpenLab Agilent 1100 . The preparation of the samples was carried out by diluting $90 \mu \mathrm{L}$ of the corresponding phase of the "volcano"-like gels, Phase A or Phase B, in $310 \mu \mathrm{L}$ of acetonitrile. The resulting solution was filtered using a PTFE $0.2 \mu \mathrm{m}$ filter before injection.

Circular dichroism (CD). CD spectra were recorded using a Jasco J-1100 spectropolarimeter with a data pitch of $1 \mathrm{~nm}$ on the light wavelength. For measurements, $40 \mu \mathrm{L}$ of the Phase A or Phase B from the contracted "volcano"-like hydrogels, formed by contact of Fmoc-FFpY (1.0 mg.mL-1) with NPs@AP $\left(1.25 \%\right.$ w/v, eq. [AP] = 2.5 units.mL $\left.\mathrm{m}^{-1}\right)$, were placed between two quartz slides of $1 \mathrm{~mm}$ thickness.

\section{Results and discussion}

Self-assembly of peptide on NPs@AP in diluted solution. We first synthesized silica NPs with an average size of $117.5 \pm 6.1 \mathrm{~nm}$ and a hydrodynamic diameter of $\sim 155 \mathrm{~nm}$ following a reported procedure $^{12}$ (Figure S1 in the Supporting Information, SI). Subsequently, AP was covalently grafted on the surface of the silica NPs using an epoxy silane coupling agent, giving rise to NPs@AP. The presence of AP on the silica NPs was first confirmed by FTIR spectroscopy (Figure S2 in SI) showing a band centered at $1633 \mathrm{~cm}^{-1}$ corresponding to the amine I band of AP. The catalytic activity of NPs@AP was checked using $p$-Nitrophenyl Phosphate (PNP) as a model substrate. After establishing the calibration curve of the enzyme free in solution (catalytic activity vs AP concentration), the concentration of active AP grafted on NPs was determined before and after several rinsing steps with the buffer (Figure S3 in SI). Several rinsing steps ensured that all the enzymes were firmly fixed on the NPs. After five rinsing steps based on centrifugation and resuspension cycles in the buffer, the supernatant showed no detectable enzymatic activity. 
NPs@AP suspension with a solid content of 5\% (w/v) was obtained with an equivalent activity in AP between 10 and 30 units. $\mathrm{mL}^{-1}$, depending on the batch. Once the enzyme was localized on the surface of the NPs, these were employed as catalytic supports for the localized growth of peptide supramolecular hydrogels. For that purpose, the low molecular weight hydrogelator Fmoc-FFY was generated in situ by enzymatic dephosphorylation of Fmoc-FFpY in presence NPs@AP (Scheme 1a). All experiments were performed at room temperature $\left(20^{\circ} \mathrm{C}\right)$.

The formation of self-assembled peptide networks over time around NPs@AP was first followed by DLS using a NPs@AP solution diluted at $0.03 \%$ w/v (eq. [AP] $=0.2$ units.mL $\mathrm{L}^{-1}$ ) and two different concentrations in Fmoc-FFpY, $0.1 \mathrm{mg} \cdot \mathrm{mL}^{-1}$ (Figure 1a) and $1 \mathrm{mg} \cdot \mathrm{mL}^{-1}$ (Figure S4 in SI). These two peptide concentrations did not lead to a gel formation allowing DLS measurements. At $0.1 \mathrm{mg} \cdot \mathrm{mL}^{-1}$ of Fmoc-FF $p$ Y, the hydrodynamic diameter of NPs@AP increased roughly from 220 $\mathrm{nm}$ up to $260 \mathrm{~nm}$ after $7 \mathrm{~h}$ (Figure 1a). After $24 \mathrm{~h}$, two different peaks were observed, one centered at $705 \mathrm{~nm}$ and the other at $5 \mu \mathrm{m}$. The initial increase of the hydrodynamic diameter from 220 to $260 \mathrm{~nm}$ in $7 \mathrm{~h}$ should be due to the formation and growth of the nanofiber networks around the NPs leading to the peak centered at $705 \mathrm{~nm}$ after $24 \mathrm{~h}$. The peak centered at $5 \mu \mathrm{m}$ could be due to the formation of nanogels constituted of several NPs surrounded by their fibrous peptide networks. This effect is more pronounced in the case of a higher concentration of Fmoc-FFpY, 1 mg.mL ${ }^{-1}$ showing a faster increase of the hydrodynamic diameter of NPs@AP after the contact with Fmoc$\mathrm{FF} p \mathrm{Y}$ and a faster appearance of the second peak (Figure S4 in SI). It must be noticed that the given sizes are obtained by applying the model of a Brownian sphere and thus should not be taken as representing rigorously the size of the scattering object but only reflecting their average hydrodynamic size. They nevertheless show a trend: the self-assembly leads to a continuous increase of size of the particles indicating the formation of a network around the NPs. 

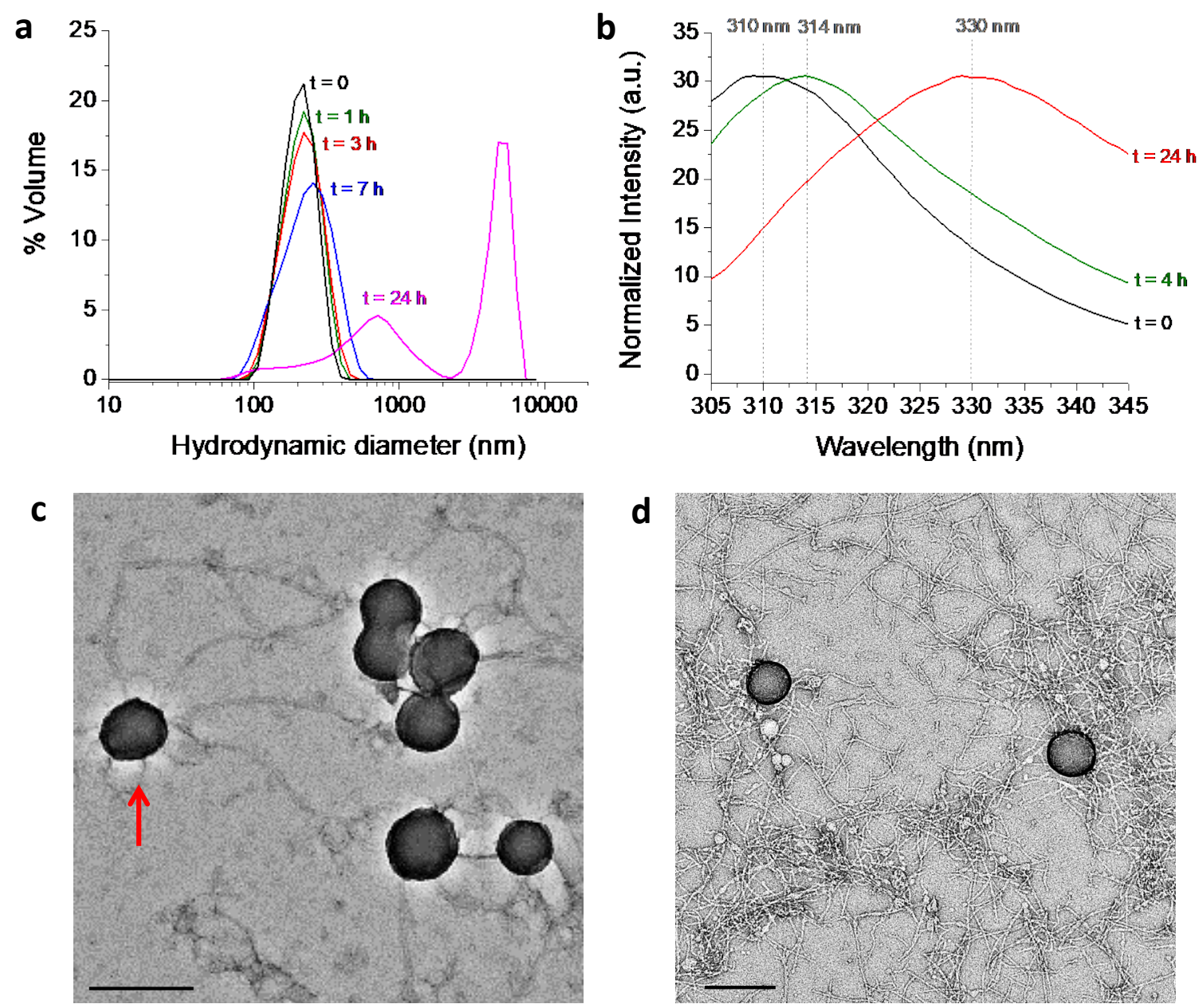

Figure 1. (a) Evolution of the hydrodynamic diameter, measured by DLS, as a function of time of NPs@AP $\left(0.03 \%\right.$ w/v, eq. $[\mathrm{AP}]=0.2$ units. $\left.\mathrm{mL}^{-1}\right)$ in contact with $0.1 \mathrm{mg} \cdot \mathrm{mL}^{-1}$ Fmoc-FFpY. (b) Fluorescence emission spectra $\left(\lambda_{\mathrm{ex}}=290 \mathrm{~nm}\right)$ of Fmoc-FF $p$ Y in the absence (black line) and in the presence of NPs@AP $\left(1.25 \%\right.$ w/v, eq. [AP] = 7.5 units.mL $\left.\mathrm{m}^{-1}\right)$ after 4 h (green line) and 24 h (red line). (c) TEM images of Fmoc-FFY fibers formed from NPs@AP after $1 \mathrm{~h}$ and (d) $4 \mathrm{~h}$. The scale bars represent $200 \mathrm{~nm}$. The arrow in (c) highlights the nanofibers that grow in all directions from NPs@AP.

The in situ formation of Fmoc-FFY and its resulting self-assembly was evidenced by the presence of the Fmoc excimer signature, usually observed in peptide-based self-assemblies in water using 
fluorescence emission spectroscopy (Figure 1b). ${ }^{24,31}$ Fmoc-FFpY solution $(t=0)$ exhibits an emission of fluorescence centered at $310 \mathrm{~nm}$ when excited at $290 \mathrm{~nm}$ due to the presence of the aromatic Fmoc group. In the presence of NPs@AP $\left(1.25 \%\right.$ w/v, eq. $[\mathrm{AP}]=7.5$ units.mL $\left.\mathrm{m}^{-1}\right)$, a shift of the fluorescence emission takes place over time, $314 \mathrm{~nm}$ after $4 \mathrm{~h}$ and $330 \mathrm{~nm}$ after $24 \mathrm{~h}$, due to the Fmoc excimer formation, indicating Fmoc-FFY self-assembly. Using the same AP concentration in solution $\left(7.5\right.$ units. $\left.\mathrm{mL}^{-1}\right)$, the Fmoc excimer formation is faster when AP is located on the surface of the silica NPs than when free in solution (Figure S5 in SI). In the latter case, a slight shift up to $317 \mathrm{~nm}$ is observed after $24 \mathrm{~h}$ and it is necessary to wait until $48 \mathrm{~h}$ to observe the shift at $330 \mathrm{~nm}$. This can be due to a local enhancement of the enzyme concentration when adsorbed on NPs, in agreement with previous reported work. ${ }^{28}$

The formation of the self-assembled peptide fibers from NPs@AP was also characterized by TEM to observe the growth of the nanofibers from AP-coated NPs. Diluted concentration of NPs@AP, i.e. $0.03 \% \mathrm{w} / \mathrm{v}$ (eq. $[\mathrm{AP}]=0.2$ units. $\mathrm{mL}^{-1}$ ), was put in contact on a TEM grid followed by a drop of Fmoc-FFpY (1 mg.mL $\left.{ }^{-1}\right)$. After $1 \mathrm{~h}$ and $4 \mathrm{~h}$, the sample was dried before measurement. Several micrometer long fibers (of $10 \mathrm{~nm}$ in diameter) were observed, often originating from the surfaces of the NPs (Figures 1c and 1d). . An increase in the density of fibers is observed with time giving rise to a denser network. No fibers were observed in areas without NPs supporting the idea that fibers are formed only from AP-coated NPs

Hybrid supramolecular hydrogel obtained from NPs@AP concentrated solution. The formation of Fmoc-FFY self-assembled hydrogels from NPs@AP was then studied by varying the quantity of NPs@AP between 0.12 and 2.5\%w/v (eq. AP concentration between 1 and 15 units.mL $\mathrm{m}^{-1}$ ) while keeping constant the peptide concentration at $1 \mathrm{mg} \cdot \mathrm{mL}^{-1}$. Hydrogelation tests were performed in 
glass vials. After $24 \mathrm{~h}$ of contact between NPs@AP and Fmoc-FFpY at room temperature, the inverted vial test was performed (Figure 2).
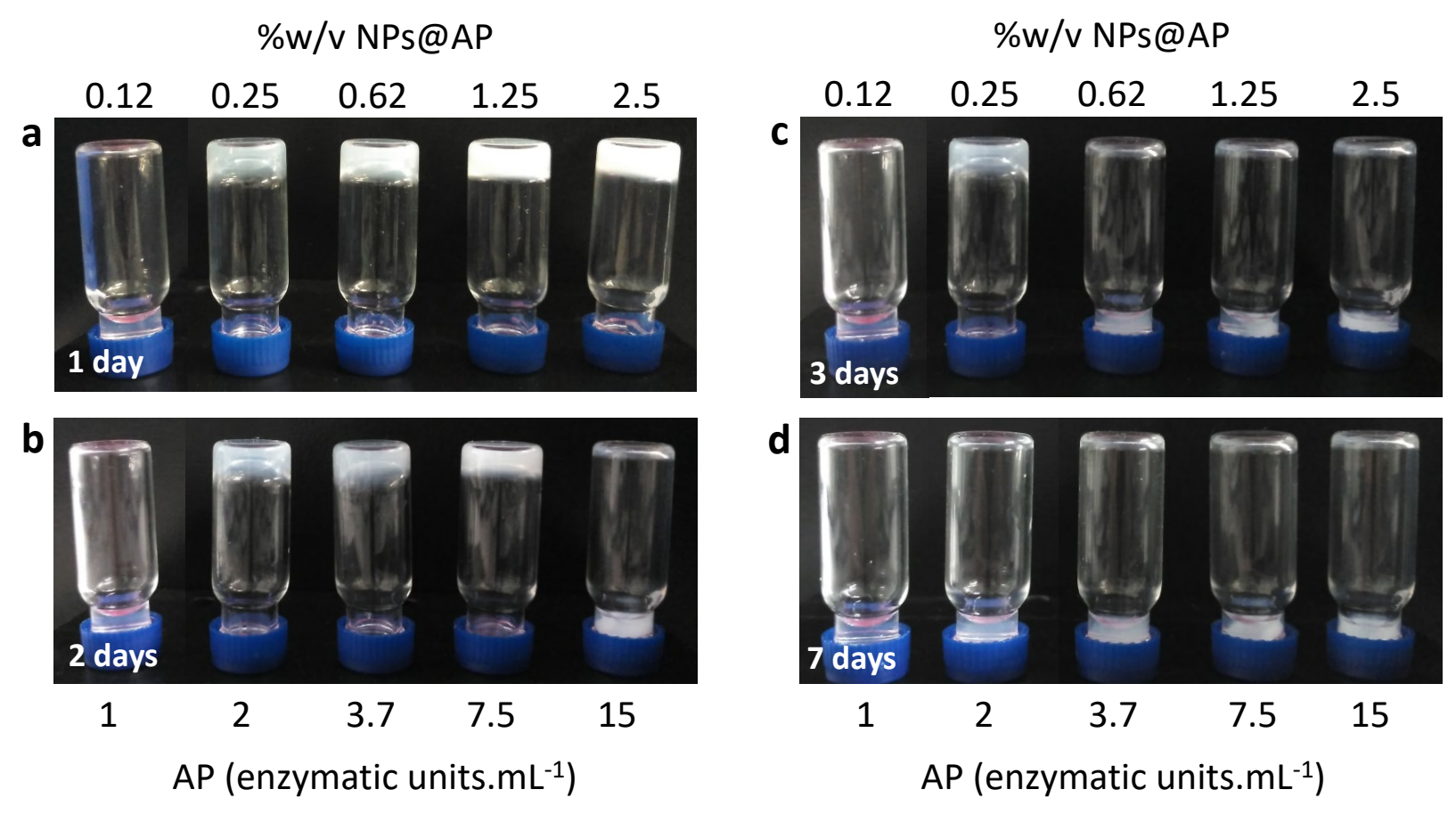

Figure 2. Inverted tube tests of Fmoc-FFp $\mathrm{Y}\left(1 \mathrm{mg} \cdot \mathrm{mL}^{-1}\right)$ in contact with different concentrations of NPs@AP, with the equivalent in AP concentration, after (a) 1 day, (b) 2 days, (c) 3 days and (d) 7 days.

No gelation was observed below $0.12 \%$ w/v of NPs@AP whereas gels formed above $0.25 \%$ w/v. To prove that gelation comes from the dephosphorylation of Fmoc-FFpY in the presence of AP located on the surface of the silica NPs, two experiments were carried out. Fmoc-FFpY (1 mg.mL $\left.{ }^{1}\right)$ was put in contact with non-functionalized NPs $(1.25 \% \mathrm{w} / \mathrm{v})$, i.e. in the absence of grafted enzymes. Fmoc-G (G: glycine), a peptide which does not self-assemble in the presence of AP, was brought in contact with NPs@AP $\left(1.25 \%\right.$ w/v, eq. 7.5 units.mL $\left.\mathrm{m}^{-1}\right)$. After $24 \mathrm{~h}$ in both cases, no gelation was observed (Figure S6 in SI) and NPs sedimented on the bottom of the vial. FTIR 
spectra of short peptides are sensitive to their secondary structure, especially in the amide I region $\left(1600-1700 \mathrm{~cm}^{-1}\right) .{ }^{32}$ In solution, Fmoc-FFpY spectrum shows a broad amide I band (CO-NH) centered around $1645 \mathrm{~cm}^{-1}$ which is commonly assigned to disordered amide groups. A broad carboxylate $\left(\mathrm{COO}^{-}\right)$vibrational band is also visible at $1590 \mathrm{~cm}^{-1}$ related to the deprotonated form of the terminal carboxylic acid groups (Figure $\mathrm{S} 7 \mathrm{in} \mathrm{SI}$ ). The peak at $1685 \mathrm{~cm}^{-1}$ is assigned to carbamate moiety. In the case of Fmoc-FFY hydrogel formed with NPs@AP, we observed a shift of the amide I band to lower frequency $\left(1632 \mathrm{~cm}^{-1}\right)$ which is the signature of aggregation via intermolecular hydrogen bonding, i.e. $\beta$-sheet structure. ${ }^{33}$ At the same time, the carboxylate and carbamate peaks are shifted to higher frequencies, 1595 and $1687 \mathrm{~cm}^{-1}$, respectively.

Unexpectedly, the hybrid hydrogels dropped down when the vials were inverted after few days (Figure 2), happening faster when the NPs@AP concentration is increased. For example, the falling down is observed after 7 days at $0.25 \%$ w/v NPs@AP and only 2 days at 2.5\% w/v suspension. This phenomenon is due to a phase separation in the vial which takes place over time, leading to two phases: one phase appears highly opaque, white and centered in the vial (phase A) and the other is transparent and colorless (phase B) surrounding phase A (Figure 3).

$\mathbf{a}$

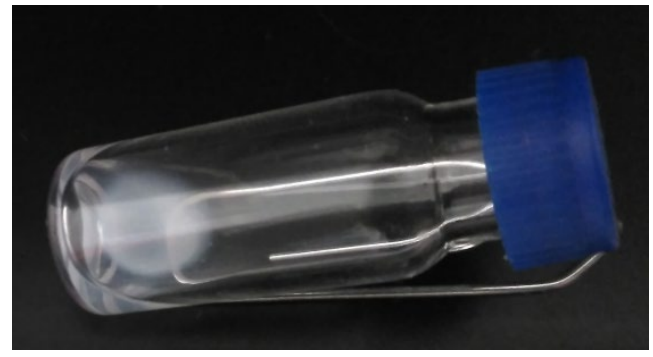

b

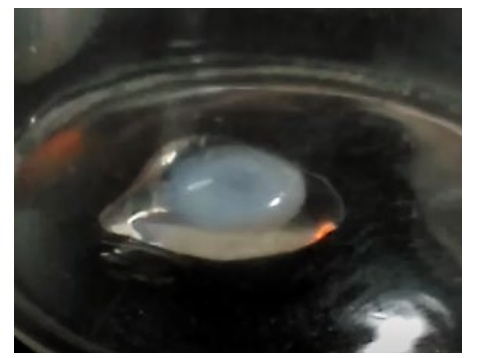

Figure 3. Hydrogel, obtained from a mixture of 1.25\% w/v NPs@AP (eq. $[\mathrm{AP}]=7.5$ units.mL $\mathrm{m}^{-1}$ ) and $1 \mathrm{mg} \cdot \mathrm{mL}^{-1} \mathrm{Fmoc}-\mathrm{FF} \mathrm{Y}$, which underwent a phase separation after 2 days (a) observed in a vial and (b) observed after its transfer in a petri dish. 
As can be seen on movie V1 in ESI, phases A and B look like the yellow and the white part of an "egg", the opaque and dense phase A being embedded in the transparent and viscous phase B. Phase B behaves as the white part of an egg when manipulated with a spatula. This phase separation leads to less adhesion between the initially (bulky) formed hydrogel and the walls of the vial, resulting in its falling down when the vial is inverted. It must be noted that in the absence of NPs a transparent hydrogel stable over two weeks is obtained using Fmoc-FFpY $\left(1 \mathrm{mg} \cdot \mathrm{mL}^{-1}\right)$ and $\mathrm{AP}$ in solution (Figure $\mathrm{S} 8$ in SI).

The morphology of the gel obtained using 1.25\%w/v of NPs@AP (eq. [AP] = 7.5 units.mL $\mathrm{m}^{-1}$ ) was visualized by cryo-SEM (Figures $4 \mathrm{a}$ and S9-10 in SI). After $24 \mathrm{~h}$, a homogeneous density of the fiber-network in the whole gel is observed. Thinner fibers have a diameter around $30 \mathrm{~nm}$. Magnification of the image allowed to distinguish isolated NPs in dark grey color with a perfectly circular shape (Figure 4a right), similar to the size of isolated NPs@AP (Figure S11 in SI). NPs play the role of crosslinking points within the 3D fibrous network and are present in the entanglements in the whole hydrogel network. For comparison, cryo-SEM image of a gel obtained without NPs, i.e. by mixing $5 \mathrm{mg} \cdot \mathrm{mL}^{-1}$ of Fmoc-FFpY and AP (10 units. $\left.\mathrm{mL}^{-1}\right)$, show a homogeneous fibrillary structure with non-circular holes (Figure S12 in SI). After 3 days allowing the phase separation, the morphologies of phases A and B obtained from the "egg" like gel were also observed (Figures $4 \mathrm{~b}$ and S10 in SI). 
a

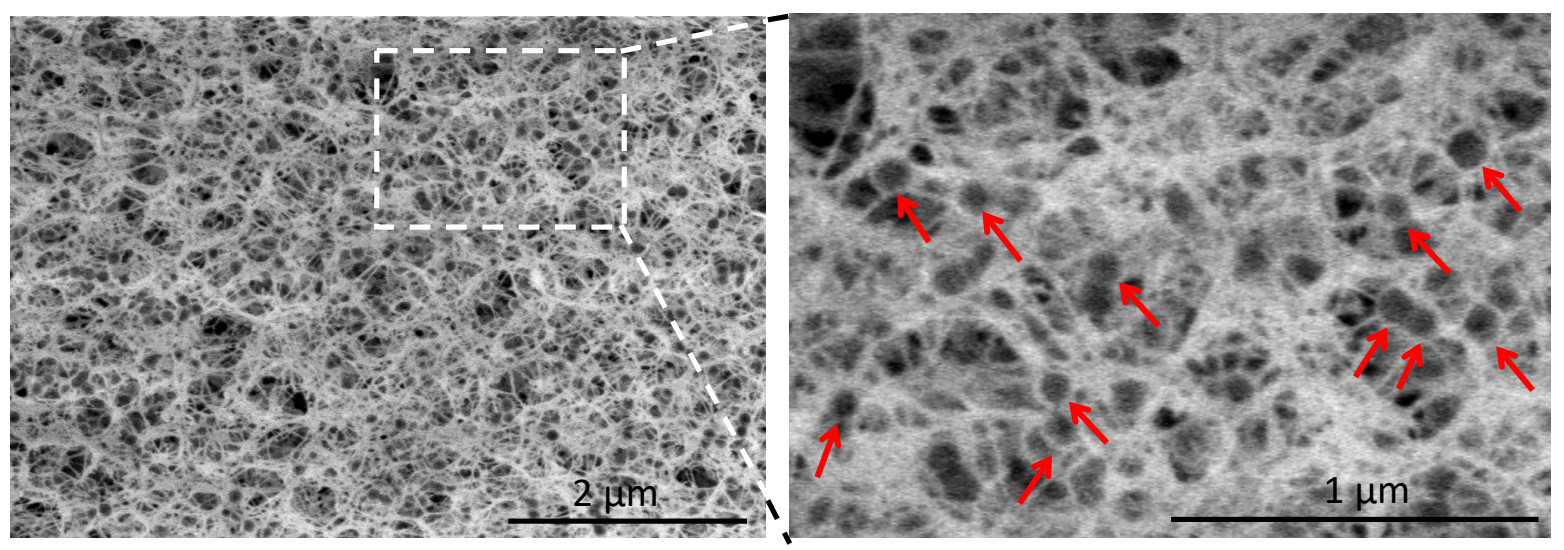

b

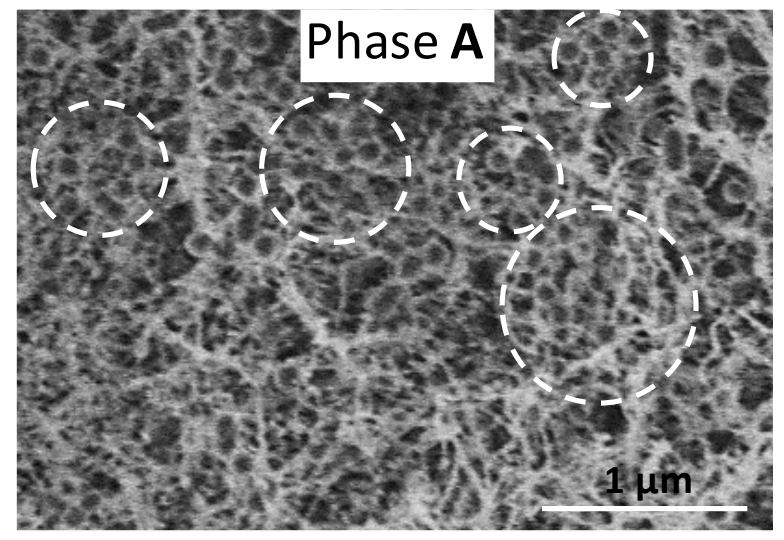

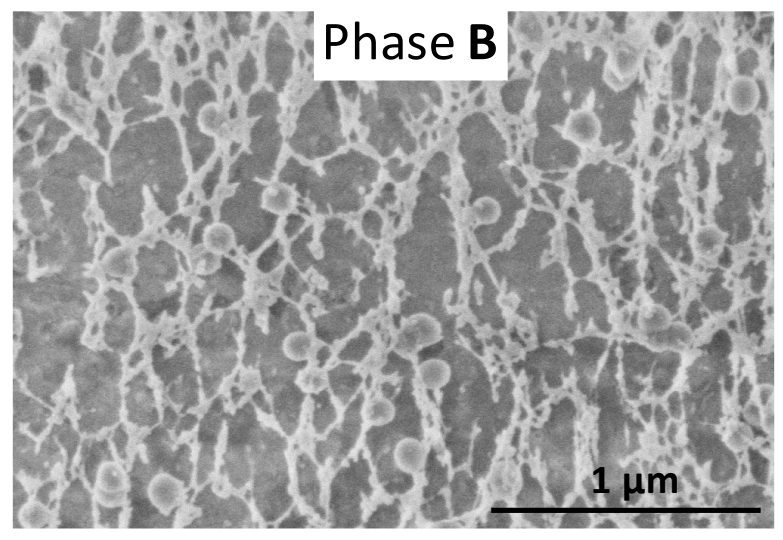

Figure 4. Cryo-SEM images of the Fmoc-FFY hydrogel, obtained from a mixture of $1.25 \% \mathrm{w} / \mathrm{v}$ $\mathrm{NPs@AP} \mathrm{(eq.} \mathrm{[AP]} \mathrm{=} 7.5$ units.mL $L^{-1}$ ) and 1 mg.mL $L^{-1}$ Fmoc-FFpY, observed after (a) 24 h (left) and zoom-in highlighting single nanoparticles with red arrows (right). (b) 2 days with the phase A (left) and phase B (right) of the "egg"-like phase separation over time.

Phase A shows a higher density in Fmoc-FFY fibers and in NPs@AP with the presence of more NPs aggregates in comparison to the bulky gel observed after $24 \mathrm{~h}$. Phase B is characterized by a much lower density of both nanofibers and NPs@AP, the density difference being even larger when compared to the dense phase A. This is expected because of conservation of matter. These observations justify the term "dense" and "dilute" to describe phases A and B. This is schematically represented in scheme $1 \mathrm{c}$. 
Keeping NPs@AP concentration fixed at 1.25\%w/v (eq. [AP] $=7.5$ units. $\mathrm{mL}^{-1}$ ), a faster phase separation is obtained by decreasing the peptide concentration from 2.5 to $0.5 \mathrm{mg} \cdot \mathrm{mL}^{-1}$ (Figure 5).
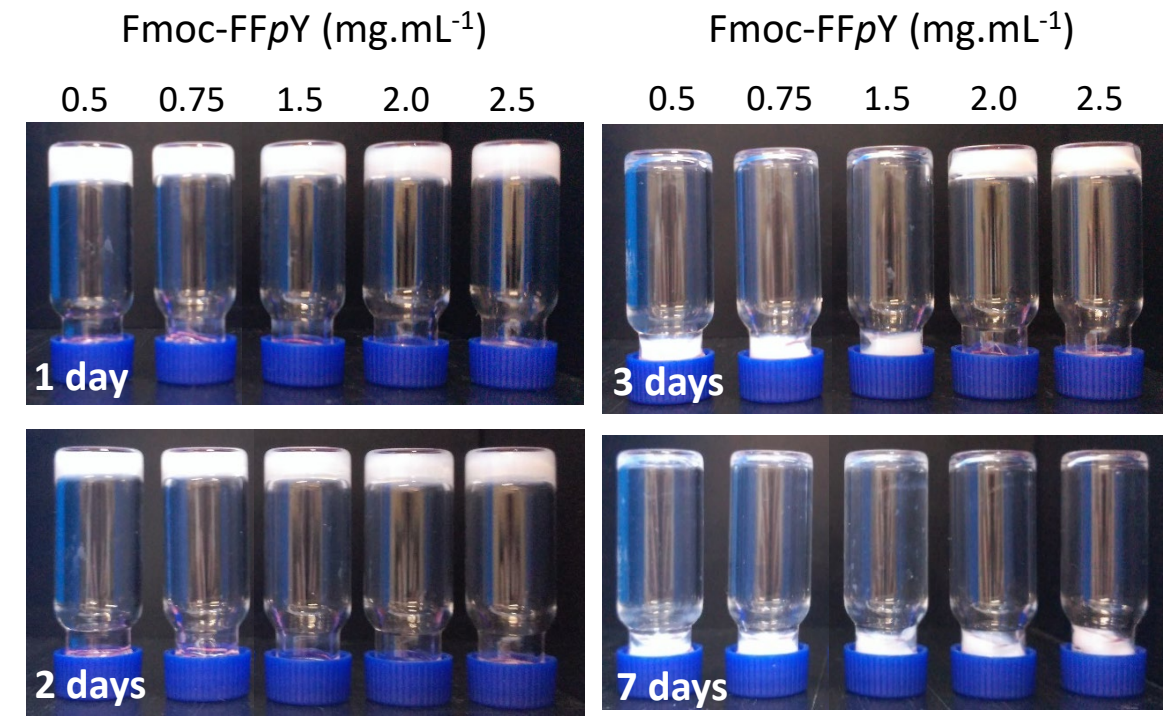

Figure 5. Inverted tube tests of NPs@AP $\left(1.25 \%\right.$ w/v, eq. $[A P]=7.5$ units. $\left.\mathrm{mL}^{-1}\right)$ in contact with different concentrations of Fmoc-FFpY after (a) 1 day, (b) 2 days, (c) 3 days and (d) 7 days.

Two different batches of NPs@AP, with an enzymatic activity of 30 and 10 units.mL ${ }^{-1}$ for a suspension of $5 \% \mathrm{w} / \mathrm{v}$, were used to follow the phase separation over time (Figure S13 and S14 in SI). The volume of the dense phase shrunk, reaching a final shape after several days or weeks depending upon the NPs batch used. For both NPs@AP activity, different shapes of phase A were observed depending upon the volume of the solution of Fmoc-FFpY and NPs@AP in the vial (Figure 6). An "egg-like" shape is observed for smaller gel volumes $(200 \mu \mathrm{L})$ and a "volcano-like" shape for larger ones $(>200 \mu \mathrm{L})$. By looking carefully to both shapes, the "egg-like" structure is similar to the bottom part of a "volcano-like" structure. For small volumes, a "volcano-like" shape cannot be formed due probably to the meniscus of liquid/air interface. 
a

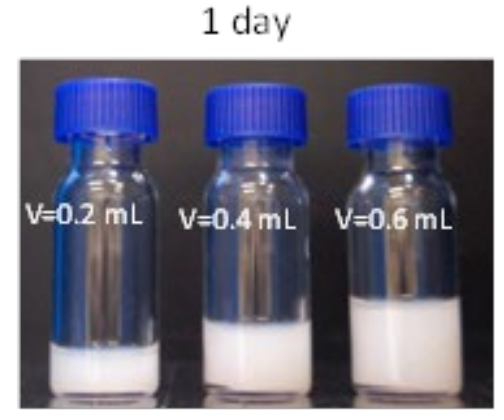

b

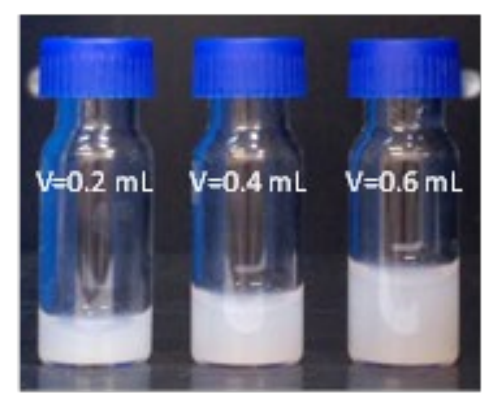

10 days
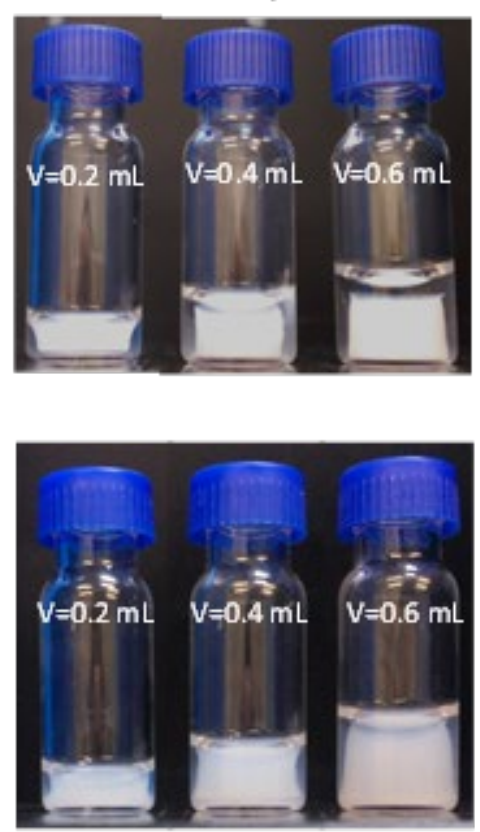

28 days
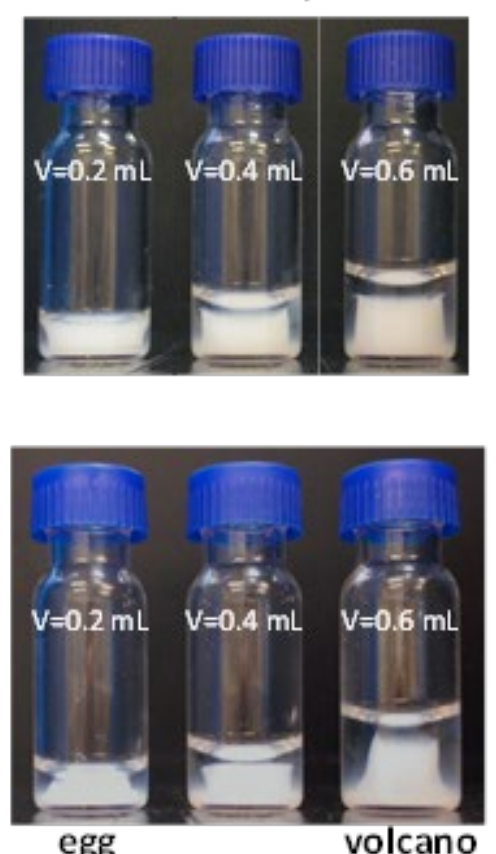

Figure 6. Phase separation observed over time, when the vials are not inverted, of NPs@AP and $1 \mathrm{mg} \cdot \mathrm{mL}^{-1}$ Fmoc-FFpY mixture with (a) NPs@AP $\left(2.5 \%\right.$ w/v, eq. [AP] $=15$ units.mL $\left.\mathrm{mL}^{-1}\right)$ and (b) NPs@AP $\left(1.25 \%\right.$ w/v, eq. [AP] $=2.5$ units.mL $\left.\mathrm{mL}^{-1}\right)$.

To be more quantitative, we determined the ratio of the volume of phase $\mathrm{A}\left(\mathrm{V}_{\mathrm{t}}\right)$ with respect to the total volume $\left(\mathrm{V}_{0}\right)$ of the solution as a function of time (Figure 7). Using the photographic pictures obtained from $600 \mu \mathrm{L}$ as initial volume obtained in Figures S13 and S14 (in SI), the area of phase A was divided into thin slits of truncated cones, characterized by two characteristic radii. Assuming a symmetrical shape of phase A, the volume of each truncated cones were determined using the adequate mathematical formulae and then were added them up to obtain the volume of phase A (for more details see SI). Hydrogels, obtained from $1 \mathrm{mg} \cdot \mathrm{mL}^{-1}$ Fmoc-FF $p$ Y mixed with $\mathrm{NPs} @ \mathrm{AP}$ at $2.5 \% \mathrm{w} / \mathrm{v}$ (eq. $[\mathrm{AP}]=15$ units. $\left.\mathrm{mL}^{-1}\right)$ and $1.25 \% \mathrm{w} / \mathrm{v}\left(\mathrm{eq}[\mathrm{AP}]=2.5\right.$ units. $\mathrm{mL}^{-1}$ ), contracted until $40 \%$ of their initial volume after 10 and 20 days, respectively. 

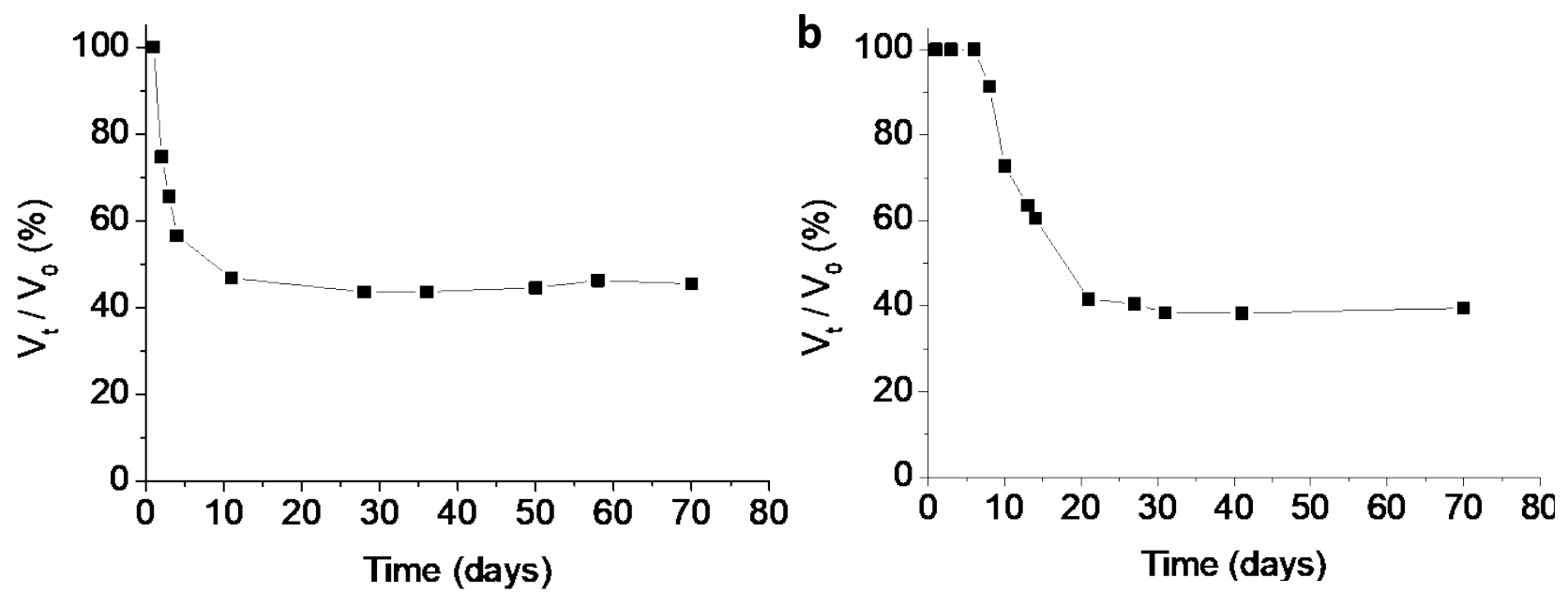

Figure 7. Evolution of the volume contraction of the hydrogels obtained in $600 \mu \mathrm{L}$ of mixture with (a) NPs@AP (2.5\% w/v, eq. [AP] = 15 units.mL $\left.{ }^{-1}\right)$ mixed with 1 mg.mL $\mathrm{m}^{-1}$ Fmoc-FFpY and (b) NPs@AP $\left(1.25 \%\right.$ w/v, eq $[\mathrm{AP}]=2.5$ units.mL $\left.\mathrm{mL}^{-1}\right)$ mixed with 1 mg.mL $\mathrm{m}^{-1}$ Fmoc-FFpY. The volume contraction was calculated as the ratio of the volume of phase $A\left(V_{t}\right)$ with respect to the total volume of the solution $\left(\mathrm{V}_{0}\right)$.

To determine if the phase separation is only observed when the enzyme is grafted on the surface of NPs, we performed experiments with gels obtained in the presence of non-functionalized NPs with Fmoc-FFpY and AP (Figure S15 in SI). Fmoc-FFpY at $1 \mathrm{mg} \cdot \mathrm{mL}^{-1}$ and non-functionalized NPs at $1.25 \% \mathrm{w} / \mathrm{v}$ were added to the AP solution at 7.5 units. $\mathrm{mL}^{-1}$. NPs sedimentation is observed after two days which probably originates from NPs aggregation in a gel which is not dense enough to avoid the sedimentation of these aggregates. We thus performed experiments by increasing the enzyme concentration at 500 units. $\mathrm{mL}^{-1}$. The obtained gel remains stable over weeks without any indication of a phase separation. This indicates that the observed phase separation is intimately related to the fact that the enzymes are covalently linked to the NPs and not just to the presence of the NPs. 
What could be the origin of this phase separation? One can only speculate at this point about it. First of all, one can ask if the observed phase separation is a syneresis process? Syneresis is a contraction of a gel with expulsion of solvent (here water). ${ }^{34}$ It originates from the fact that the solvent is not a good solvent for the gel material which leads to an increase of the density of chain/chain interactions in the gel. Syneresis was already observed on peptides self-assembled hydrogels. ${ }^{35-36}$ In our case the "dilute" phase (phase B) is not only constituted of water, as it should be for syneresis, but also of supramolecular peptide self-assemblies and NPs. This is seen by the highly viscous nature of the phase B of the "egg"-like structure (see Video SI) and its characterization by cryo-SEM revealing the presence of NPs and fibers (Figure $4 \mathrm{~b}$ left). Fibers linked to NPs were also observed in Phase B of the "volcano-like" structure (Figure S16 in SI). We further verified the presence of Fmoc-FFyP peptides in the "dense" (phase A) and the "dilute"(phase B) phase of "volcano-like" structure using HPLC. The peptides are present in both phases, with a much smaller concentration in phase B (Figure S17 in SI). The ratio of the peptide concentration found in phase $\mathrm{B}$ over phase $\mathrm{A}$ is of the order of $6 \%$ (Table $\mathrm{S} 1$ in SI). The NPs cannot be detected by HPLC because they were retained by the column. Finally, by performing CD experiments on the "dilute" and "dense" phase, we observed a similar CD signal in both phases, with much smaller intensity for phase B (Figure S18 in SI). There are two intense bands, a negative one at $203 \mathrm{~nm}$ and a positive one at $228 \mathrm{~nm}$ both attributed to $\pi-\pi$ interactions between phenyl side chains. $^{37}$ Supramolecular hydrogels are dynamic entities where self-assembly and disassembly of the peptide fibers take place constantly. Moreover, NPs have a tendency to attract each other thanks to van der Waals forces and to aggregate over time when left in solution even inside a gel. ${ }^{38}$ One can thus assume that such attraction between NPs takes also place in the gel with time. Now it is known that the peptide fibers also interact with the enzymes ${ }^{39}$ and thus with 
the NPs covered by enzymes. These favorable interactions between the NPs and the fibers should also favor a fiber network densification. This densification process of both the NPs and the peptide fibers is then accompanied by a reduction of the peptide density at the periphery of the dense part (Phase A) leading to the appearance of a dilute Phase B. Moreover, the NPs at the periphery of phase A have less neighbors than those inside phase A and are thus less attracted by other particles. These particles then diffuse to and from phase B. Such a phase separation is not observed when the enzymes are not covalently fixed on the NPs indicating that the strong interaction between the fibers and the NPs (through the enzymes here) is required for this phase separation to take place. All these hypotheses have to be addressed in further studies in greater details.

\section{Conclusion}

We investigated peptide supramolecular hydrogels initiated at the surface of AP-coated silica NPs through localized enzyme-assisted self-assembly processes. Using DLS and TEM we confirmed the nucleation of self-assembled peptide nanofibers from the NPs surface. At adequate concentrations of peptides Fmoc-FFpY and NPs@AP, the self-assembly process leads to the formation of a hydrogel in the bulk. Such a supramolecular hydrogel evolves over time leading to a phase separation different from syneresis: a core phase composed of high densities of peptide nanofibers and aggregated NPs and an outer phase, with the consistency of a gel, with more diluted peptide nanofibers and NPs. Such a phase separation requires the attachment of the enzymes on the NPs. It is hypothesized that attraction between the NPs is at the origin of the phase change but further studies are needed to get a clear picture of this morphological evolution, so far, to our knowledge, never observed. The understanding and the control of both the spatial localization of molecular self-assembly processes and their evolution over time leading to the design of nanometer up to macroscopic scale chemical system is a sine qua none condition towards the development of 
highly complex materials such as artificial living matter. That is why we expect that our contribution will interest a large part of the research community.

\section{ASSOCIATED CONTENT}

\section{Supporting Information}

The following files are available free of charge. TEM image and histogram of NPs, DLS spectrum of NPs, ATR-FTIR spectra of NPs and NPs@AP, calibration curve of AP in solution and activity of NPs@AP, DLS spectra of NPs@AP in the presence of Fmoc-FFpY, fluorescence spectra of AP and Fmoc-FFpY, inverted tube tests of NPs mixed with Fmoc-FFpY and NPs@AP mixed with Fmoc-G, inverted tube tests of AP at different concentrations mixed with Fmoc-FFpY, FTIR spectra of Fmoc-FFpY and NPs@AP, Cryo-SEM images of NPs@AP/Fmoc-FFY hydrogel after 1 and 2 days and AP/Fmoc-FFY hydrogel, pictures of phase transition evolution over the time of NPs@AP mixed with Fmoc-FF $p$ Y and non-functionalized NPs mixed with AP and Fmoc-FF $p$ Y in solution, HPLC and CD spectra of phases A and B, volume calculation of phase A.

\section{ACKNOWLEDGMENT}

M.C.-G. acknowledges IDEX of Université de Strasbourg for granting post-doctoral fellowship. J.R.F. acknowledges International Center for Frontier Research in Chemistry (Labex CSC, PSC016 and PSC-005) for $\mathrm{PhD}$ fellowship. ICS microscopy platform and ICS characterization platform are acknowledged for the use of the SEM and DLS instruments respectively. We gratefully acknowledge the financial supports from Agence Nationale de la Recherche (EASA, ANR-18-CE06-0025-03) and Institut Carnot-MICA (DIAART).

\section{REFERENCES}


(1) Lehn, J.-M. Perspectives in Chemistry-Aspects of Adaptive Chemistry and Materials. Angew. Chem., Int. Ed. Engl. 2015, 54, 3276-3289.

(2) Grzybowski, B. A.; Huck, W. T. S. The Nanotechnology of Life-Inspired Systems. Nat. Nanotechnol. 2016, 11, 585-592.

(3) Leira-Iglesias, J.; Tassoni, A.; Adachi, T.; Stich, M.; Hermans, T. M. Oscillations, Travelling Fronts and Patterns in a Supramolecular System. Nat. Nanotechnol. 2018, 13, 1021-1027.

(4) Marchetti, M. C.; Joanny, J. F.; Ramaswamy, S.; Liverpool, T. B.; Prost, J.; Rao, M.; Simha, R. A. Hydrodynamics of Soft Active Matter. Rev. Mod. Phys. 2013, 85, 1143-1189.

(5) Boekhoven, J.; Hendriksen, W. E.; Koper, G. J. M.; Eelkema, R.; van Esch, J. H. Transient Assembly of Active Materials Fueled by a Chemical Reaction. Science 2015, 349, 1075-1079.

(6) Mann, S. Life as a Nanoscale Phenomenon. Angew. Chem., Int. Ed. Engl. 2008, 47, 5306-5320.

(7) Komiyama, M.; Yoshimoto, K.; Sisido, M.; Ariga, K. Chemistry Can Make Strict and Fuzzy Controls for Bio-Systems: DNA Nanoarchitectonics and Cell-Macromolecular Nanoarchitectonics. Bull. Chem. Soc. Jap. 2017, 90, 967-1004.

(8) Ariga, K.; Leong, D. T.; Mori, T. Nanoarchitectonics for Hybrid and Related Materials for BioOriented Applications. Adv. Funct. Mater. 2018, 28, 23.

(9) Stuart, M. A. C.; Huck, W. T. S.; Genzer, J.; Müller, M.; Ober, C.; Stamm, M.; Sukhorukov, G. B.; Szleifer, I.; Tsukruk, V. V.; Urban, M.; Winnik, F.; Zauscher, S.; Luzinov, I.; Minko, S. Emerging Applications of Stimuli-Responsive Polymer Materials. Nat. Mater. 2010, 9, 101-113.

(10) Ziemecka, I.; Koper, G. J. M.; Olive, A. G. L.; van Esch, J. H. Chemical-Gradient Directed Self-Assembly of Hydrogel Fibers. Soft Matter 2013, 9, 1556-1561.

(11) Valignat, M.-P.; Theodoly, O.; Crocker, J. C.; Russel, W. B.; Chaikin, P. M. Reversible SelfAssembly and Directed Assembly of DNA-Linked Micrometer-Sized Colloids. Proc. Natl. Acad. Sci. U. S. A. 2005, 102, 4225-4229.

(12) Capito, R. M.; Azevedo, H. S.; Velichko, Y. S.; Mata, A.; Stupp, S. I. Self-Assembly of Large and Small Molecules into Hierarchically Ordered Sacs and Membranes. Science 2008, 319, 18121816.

(13) Winkleman, A.; Gates, B. D.; McCarty, L. S.; Whitesides, G. M. Directed Self-Assembly of Spherical Particles on Patterned Electrodes by an Applied Electric Field. Adv. Mater. 2005, 17, 1507-1511.

(14) Sone, E. D.; Zubarev, E. R.; Stupp, S. I. Semiconductor Nanohelices Templated by Supramolecular Ribbons. Angew. Chem., Int. Ed. Engl. 2002, 41, 1705-1709.

(15) Qing, G.; Xiong, H.; Seela, F.; Sun, T. Spatially Controlled DNA Nanopatterns by "Click" Chemistry Using Oligonucleotides with Different Anchoring Sites. J. Am. Chem. Soc. 2010, 132, $15228-15232$.

(16) Du, X.; Zhou, J.; Shi, J.; Xu, B. Supramolecular Hydrogelators and Hydrogels: From Soft Matter to Molecular Biomaterials. Chem. Rev. 2015, 115, 13165-13307.

(17) Vigier-Carrière, C.; Boulmedais, F.; Schaaf, P.; Jierry, L. Surface-Assisted Self-Assembly Strategies Leading to Supramolecular Hydrogels. Angew. Chem., Int. Ed. Engl. 2018, 57, 14481456.

(18) Yang, B.; Adams, D. J.; Marlow, M.; Zelzer, M. Surface-Mediated Supramolecular SelfAssembly of Protein, Peptide, and Nucleoside Derivatives: From Surface Design to the Underlying Mechanism and Tailored Functions. Langmuir 2018, 34, 15109-15125.

(19) Olive, A. G. L.; Abdullah, N. H.; Ziemecka, I.; Mendes, E.; Eelkema, R.; van Esch, J. H. Spatial and Directional Control over Self-Assembly Using Catalytic Micropatterned Surfaces. Angew. Chem., Int. Ed. Engl. 2014, 53, 4132-4136. 
(20) Criado-Gonzalez, M.; Rodon Fores, J.; Wagner, D.; Schröder, A. P.; Carvalho, A.; Schmutz, M.; Harth, E.; Schaaf, P.; Jierry, L.; Boulmedais, F. Enzyme-Assisted Self-Assembly within a Hydrogel Induced by Peptide Diffusion. Chem. Commun. 2019, 55, 1156-1159.

(21) Williams, R. J.; Smith, A. M.; Collins, R.; Hodson, N.; Das, A. K.; Ulijn, R. V. EnzymeAssisted Self-Assembly under Thermodynamic Control. Nat. Nanotechnol. 2008, 4, 19-24.

(22) Williams, R. J.; Hall, T. E.; Glattauer, V.; White, J.; Pasic, P. J.; Sorensen, A. B.; Waddington, L.; McLean, K. M.; Currie, P. D.; Hartley, P. G. The in Vivo Performance of an Enzyme-Assisted Self-Assembled Peptide/Protein Hydrogel. Biomaterials 2011, 32, 5304-5310.

(23) Vigier-Carrière, C.; Wagner, D.; Chaumont, A.; Durr, B.; Lupattelli, P.; Lambour, C.; Schmutz, M.; Hemmerlé, J.; Senger, B.; Schaaf, P.; Boulmedais, F.; Jierry, L. Control of SurfaceLocalized, Enzyme-Assisted Self-Assembly of Peptides through Catalyzed Oligomerization. Langmuir 2017, 33, 8267-8276.

(24) Vigier-Carrière, C.; Garnier, T.; Wagner, D.; Lavalle, P.; Rabineau, M.; Hemmerlé, J.; Senger, B.; Schaaf, P.; Boulmedais, F.; Jierry, L. Bioactive Seed Layer for Surface-Confined SelfAssembly of Peptides. Angew. Chem., Int. Ed. Engl. 2015, 54, 10198-10201.

(25) Rodon Fores, J.; Martinez Mendez, M. L.; Mao, X.; Wagner, D.; Schmutz, M.; Rabineau, M.; Lavalle, P.; Schaaf, P.; Boulmedais, F.; Jierry, L. Localized Supramolecular Peptide SelfAssembly Directed by Enzyme-Induced Proton Gradients. Angew. Chem., Int. Ed. Engl. 2017, 56, 15984-15988.

(26) Wang, Y.; Versluis, F.; Oldenhof, S.; Lakshminarayanan, V.; Zhang, K.; Wang, Y.; Wang, J.; Eelkema, R.; Guo, X.; van Esch, J. H. Directed Nanoscale Self-Assembly of Low Molecular Weight Hydrogelators Using Catalytic Nanoparticles. Adv. Mater. 2018, 30, 1707408.

(27) Wu, C.; Hu, W.; Wei, Q.; Qiao, L.; Gao, Y.; Lv, Y.; Liu, M.; Li, C.; Wang, X.; Wang, Q. Controllable Growth of Core-Shell Nanogels Via Esterase-Induced Self-Assembly of Peptides for Drug Delivery. J. Biomed. Nanotechnol. 2018, 14, 354-361.

(28) Conte, M. P.; Sahoo, J. K.; Abul-Haija, Y. M.; Lau, K. H. A.; Ulijn, R. V. Biocatalytic SelfAssembly on Magnetic Nanoparticles. ACS Appl. Mater. Interfaces 2018, 10, 3069-3075.

(29) Chang, S. M.; Lee, M.; Kim, W.-S. Preparation of Large Monodispersed Spherical Silica Particles Using Seed Particle Growth. J. Colloid Interface Sci. 2005, 286, 536-542.

(30) Wu, Y.; Chen, C.; Liu, S. Enzyme-Functionalized Silica Nanoparticles as Sensitive Labels in Biosensing. Anal. Chem. 2009, 81, 1600-1607.

(31) Smith, A. M.; Williams, R. J.; Tang, C.; Coppo, P.; Collins, R. F.; Turner, M. L.; Saiani, A.; Ulijn, R. V. Fmoc-Diphenylalanine Self Assembles to a Hydrogel Via a Novel Architecture Based on П-П Interlocked B-Sheets. Adv. Mater. 2008, 20, 37-41.

(32) Fleming, S.; Frederix, P. W. J. M.; Ramos Sasselli, I.; Hunt, N. T.; Ulijn, R. V.; Tuttle, T. Assessing the Utility of Infrared Spectroscopy as a Structural Diagnostic Tool for B-Sheets in SelfAssembling Aromatic Peptide Amphiphiles. Langmuir 2013, 29, 9510-9515.

(33) Tang, C.; Smith, A. M.; Collins, R. F.; Ulijn, R. V.; Saiani, A. Fmoc-Diphenylalanine SelfAssembly Mechanism Induces Apparent Pka Shifts. Langmuir 2009, 25, 9447-9453.

(34) Castilla, A. M.; Wallace, M.; Mears, L. L. E.; Draper, E. R.; Doutch, J.; Rogers, S.; Adams, D. J. On the Syneresis of an Opv Functionalised Dipeptide Hydrogel. Soft Matter 2016, 12, 78487854.

(35) Adams, D. J.; Mullen, L. M.; Berta, M.; Chen, L.; Frith, W. J. Relationship between Molecular Structure, Gelation Behaviour and Gel Properties of Fmoc-Dipeptides. Soft Matter 2010, 6, 1971 1980 . 
(36) Conte, M. P.; Singh, N.; Sasselli, I. R.; Escuder, B.; Ulijn, R. V. Metastable Hydrogels from Aromatic Dipeptides. Chem. Commun. 2016, 52, 13889-13892.

(37) Ryan, D. M.; Anderson, S. B.; Senguen, F. T.; Youngman, R. E.; Nilsson, B. L. Self-Assembly and Hydrogelation Promoted by F5-Phenylalanine. Soft Matter 2010, 6, 475-479.

(38) Chakrabarti, A.; Chaudhury, M. K. Surface Folding-Induced Attraction and Motion of Particles in a Soft Elastic Gel: Cooperative Effects of Surface Tension, Elasticity, and Gravity. Langmuir 2013, 29, 15543-15550.

(39) Rodon Fores, J.; Criado-Gonzalez, M.; Schmutz, M.; Blanck, C.; Schaaf, P.; Boulmedais, F.; Jierry, L. Protein-Induced Low Molecular Weight Hydrogelator Self-Assembly through a SelfSustaining Process. Chem. Sci. 2019, 10, 4761-4766. 
TOC

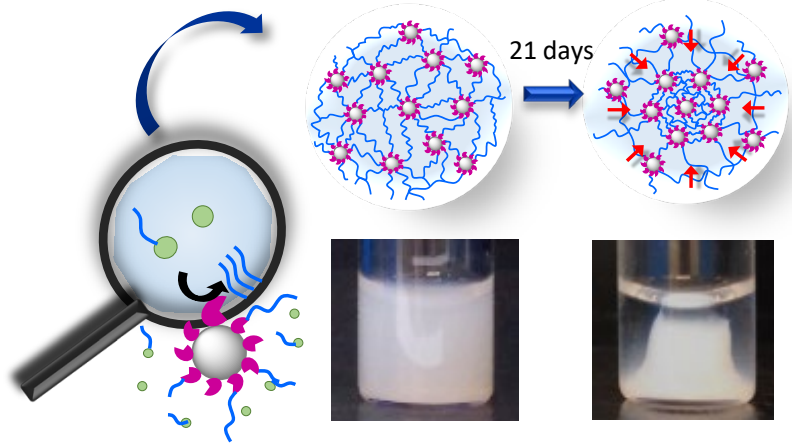

